\title{
Identifying Factors of Job Stress That Affect Job Performance among Employees in Sarawak Corporation, Malaysia
}

Puteri Faida Alya Zainuddin, Norlina Mohamed Noor, Affiana Kadri, Nur Zahariah Maimon

To Link this Article: http://dx.doi.org/10.6007/IJARBSS/v11-i2/9204

DOI:10.6007/IJARBSS/v11-i2/9204

Received: 20 December 2020, Revised: 23 January 2021, Accepted: 15 February 2021

Published Online: 28 February 2021

In-Text Citation: (Zainuddin et al., 2021)

To Cite this Article: Zainuddin, P. F. A., Noor, N. M., Kadri, A., \& Maimon, N. Z. (2021). Identifying Factors of Job Stress That Affect Job Performance among Employees in Sarawak Corporation, Malaysia. International Journal of Academic Research in Business and Social Sciences, 11(2), 1283-1293.

\section{Copyright: (C) 2021 The Author(s)}

Published by Human Resource Management Academic Research Society (www.hrmars.com)

This article is published under the Creative Commons Attribution (CC BY 4.0) license. Anyone may reproduce, distribute, translate and create derivative works of this article (for both commercial and non-commercial purposes), subject to full attribution to the original publication and authors. The full terms of this license may be seen at: http://creativecommons.org/licences/by/4.0/legalcode

Vol. 11, No. 2, 2021, Pg. 1283 - 1293

Full Terms \& Conditions of access and use can be found at http://hrmars.com/index.php/pages/detail/publication-ethics 


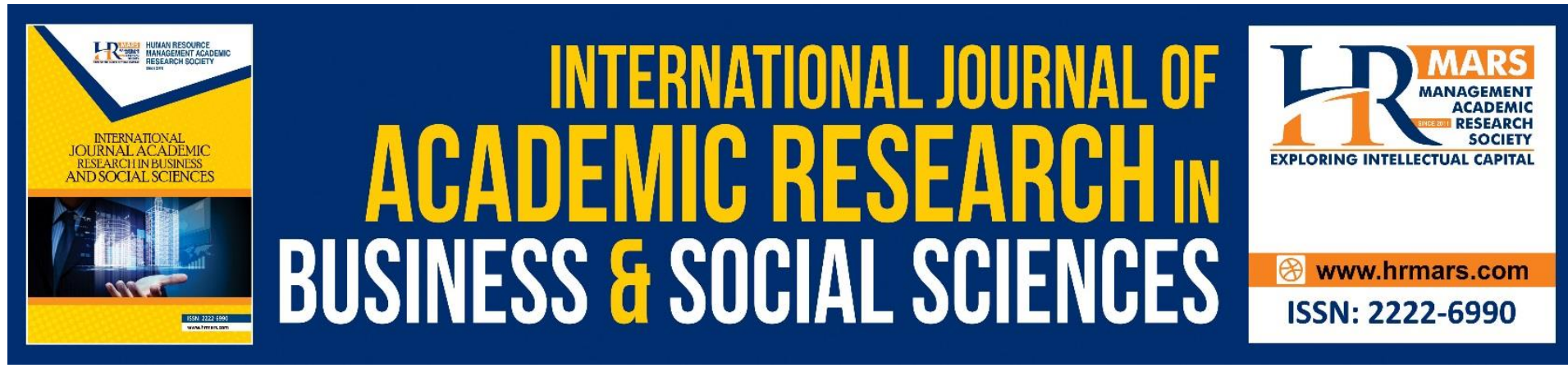

\title{
Identifying Factors of Job Stress That Affect Job Performance among Employees in Sarawak Corporation, Malaysia
}

\author{
Puteri Faida Alya Zainuddin ${ }^{1}$, Norlina Mohamed Noor ${ }^{2}$, Affiana \\ $\mathrm{Kadri}^{3}$, Nur Zahariah Maimon ${ }^{4}$ \\ ${ }^{1}$ Faculty of Computer and Mathematical Sciences, Universiti Teknologi MARA, Cawangan \\ Sarawak, 96400 Mukah, Sarawak, Malaysia, 2,4Faculty of Business and Management, \\ Universiti Teknologi MARA, Cawangan Sarawak, 94300 Kota Samarahan, Sarawak, Malaysia, \\ ${ }^{3}$ Academy of Languages Studies, Universiti Teknologi MARA, Cawangan Sarawak, 94300 Kota \\ Samarahan, Sarawak, Malaysia
}

Email: puterifaida@uitm.edu.my,norli517@uitm.edu.my,nurzahariah.maimon@gmail.com, affiana@uitm.edu.my

\begin{abstract}
Job stress is very prominent that always happens in any organizations or companies nowadays. Many factors lead to job stress, such as personal problems, financial, low salary, and others. These factors can affect employees' productivity, commitment, and professionalism to perform their task. This study explores the predictive ability of Sarawak Timber Industry Development Corporation (STIDC) employees' job stress on job performance of employees by using a sample of 80 respondents. The framework for this study was adapted and constructed based on the Job Demands-Control (JDC) Model. The data were obtained using a questionnaire with a 10-Likert scale and was distributed to all staff in the company. Based on the findings, all the independent variables have a significant association with job performance. Nevertheless, from the analysis of multiple linear regression, the results showed that time pressure and skill discretion significantly correlated to predict job performance.
\end{abstract}

Keywords: Job Stress, Workload, Time Pressure, Skill Discretion, Decision Authority, Job Performance.

\section{Introduction}

Job performance can be defined as an employee's proficiency to achieve the goals that have been set by their organization. Many factors can influence job performance for instance job satisfaction, employees involvement and management control. According to Bruggen (2015), employees' job performance can be impacted by job stress. If the employees cannot manage and maintain good job stress, they cannot improve their performance and do well. This also will lead to high absenteeism or even worse, it can increase the number of employees' resignation. As a result, the goals of the organization cannot be achieved. 
Efficiency and trust in the organization will also be declining. Thus, this study would like to explore and predict which factors of job stress can affect job performance.

In this study, Job Demands-Control (JDC) model introduced by Karasek (1979) has been used. According to the model, job stress consists of workload, time pressure, skill discretion and decision authority. Akgunduz (2015) further described that work overload is an important factor influencing job performance. Managers should pay more attention to task overload to reduce stress at work. A recent study by Hafeez (2018) has explored the association between workload and job performance. The result obtained show that employees experienced work stress if they faced great job demand in terms of workload.

However, a study found that workload has no significant effect on job performance but time pressure has contributed significantly to job performance (Johari et al, 2019). This study has been done on auditors in the National Audit Department of Malaysia and found that the auditors would perform better when a shorten time was given to complete the audit tasks. When they do not pressure with the time given, the auditors will be more relax and not focus on their job. In this context, flexibility in working time has been shown to have an impact on job efficiency.

According to Viotti and Converso (2016), employees can do a better job if they have high skill discretion. The findings obtained show that a positive impact on workers makes them more optimistic, thus enhancing their job performance. Another study by Heponiemi, Kouvonen, Virtanen, Vanska and Elovainio (2014) was held to identify the decision authority towards employees. Based on the study, they found that having a lower decision authority could negatively affect job performance. However, having a higher decision authority related to their job task would increase employees' job performance.

\section{Review of Literature Workload}

Bruggen (2015) was studied among mid-size grocery suppliers whether or not workload affects the employees' job performance. The researcher used individuals from the same department to make sure that everyone has the same expected work results with each other. Regarding their work task, a computer randomly chose an employee and the orders that they needed to process. After the research has been done, it was found that there was an inverted U-shape relationship, which meant that the quality of the employees' job performance was high when given a moderate amount of workload. However, when given too low or too high of the workloads, their job performance decreased. Next, a recent study conducted by Hafeez (2018) among the employees working at the social security hospital showed that workload influenced the performance of employees. This finding also revealed that hospital employees experienced work stress when given much workload because they are expected to cope with patients demands, heavy tasks, overtime and others. This affected service delivery to the patients and lowered their performance. Research done by Lopes et al. (2014) studied the relationship between workload and job satisfaction. The research found that there was a lack of job satisfaction due to the increase in workload. This study also stated that if there is an increase in work intensity, there is an increase in worker's satisfaction. When people are satisfied and enjoy doing their work, they will perform better and work effectively. This is because when the workers do the task that they are interested in, they also enjoy the higher workload. Another study carried out in Pakistan by Ahmed and Ramzan (2013) in banking sector employees, they examined the function of work stress and its effect on job efficiency. One of the variables for job stress was the workload. The results showed that the 
workload could reduce employees' job performance. It was found that the workload had a negative relationship with job performance. This means it can affect the performance when the stress occurs. When stress is lower, employees can perform better. In opposite, when stress is higher, employees will have more unsatisfactory performance. In this study, the employees have to work for long hours due to workloads and time constraints.

\section{Time Pressure}

Sharma and Bhatnagar (2017) noted that teams were formed due to the job demand they encountered. The individuals discovered that it was easier to work together to get the job done than to work separately. However, for the team to form, they required two elements, which were team leader engaging behavior and team climate. When a successful team was created, the work produced had better quality and the workers felt satisfied with the outcome. This was because everyone had a task he or she was responsible for. They were thus able to overcome all daunting job demands together and fulfil the time allocated to them. On the other hand, another study in Korea had found working long hours can affect the employees' health and performance (Cho et al, 2018). The employees have worked more than 52 hours a week to earn money. The management wanted their employees to work hard, however, did not care much about their employees' health status which could affect job performance. This study was recommended to the government and organization to decrease the working time for employees because working for longer hours will affect their efficiency and health.

\section{Skill Discretion}

Skill discretion applies to the variety of skills used at work. A result by Isafahani, Aryankhesal and Haghani (2014) indicated that 50\% of the sample agreed that their job performance was influenced by job skills. Job skills can be strengthened by proper training. With more training provided, indirectly, it can enhance employees job performance. According to the study conducted by Viotti and Converso (2016) on 522 nurses, a person could do better in his/her job when had high skill discretion. Employees who had lower skill discretion could have emotional exhaustion and turnover intention because nurses did a lot of tasks and they must have knowledge on how to conduct their tasks.

\section{Decision Authority}

Kumar and Saha (2017) suggested that managers ought to encourage employee trust and active involvement by taking their views on various aspects of the job. Involvement of employees in decision making can help management in giving more ideas in helping to solve organizational problems. At the same time, it can give confidence to the employees in the organization to remain loyal and increase their commitment. A study by Sia and Duari (2018) was conducted to determine the decision-making authority towards 330 employees that were below the supervisory level of manufacturing companies in Odisha. The employees were encouraged to share their views over the final decision-making process, thus the result gathered showed that decision making had a good impact on them. Due to this, it has increased the level of job performance among the employees working in manufacturing companies. A research was done in a nursing home featured that when the staff has given decision authority, they could regulate their high job demands (Willimse et al, 2012). This means that, when the worker had a lot of work to do, they would know how to make decisions on what task to do first and what to do later. This will promote the positive consequences of 
work and employees' performance. Therefore, the engagement of employees in decisionmaking can be a mechanism for empowering and rewarding employees, contributing to better job performance.

\section{Methodology}

A random sample of 80 respondents among employees at Sarawak Timber Industry Development Corporation (STIDC) was selected through a simple random sampling technique. The research instrument utilized in this study was a questionnaire. It was divided into three sections. The first section is on the demographic details. The second section is adapted from Karasek (1979), covering the independent variable where the work-related stress is found in the organization. This comprises the variables found in the Job DemandsControl Model, referring to job demand (workload and time pressure) and job control (skills discretion and decision authority). Lastly, the third section adopted from Munisamy (2013) covers items on the dependent variable, which is job performance. The questions in section 2 and 3 contain a 10-point Likert scale type ranging from (1) extremely disagree until (10) extremely agree.

Statistical Package for Social Science (SPSS) was used to tabulate the data attained from the respondents. The data were tested for inferential analysis using Pearson's coefficient correlation to identify the relationship between the independent and dependent variables. Then, Multiple Linear Regression was gathered to estimate the job performance for more than one independent variable.

\section{Finding and Results Reliability Analysis}

Table 1. Reliability coefficients

\begin{tabular}{lcc}
\hline Variables & No. of Items & Cronbach's Alpha \\
\hline Workload & 6 & .685 \\
Time Pressure & 7 & .895 \\
Skill Discretion & 5 & .899 \\
Decision authority & 6 & .838 \\
Job Performance & 9 & .957 \\
\hline
\end{tabular}

Cronbach's Alpha has been used to check the reliability of this study. Authors and researchers such as Sekaran and Bougie (2013), Nunnally (1976) and Allen and Bennett (2010) stated that a reliability value over .600 consider acceptable and value around .900 onwards is ideal. Therefore, the results in Table 1 show that all of the items were considered reliable. The table only presented the actual result without pre-test data.

\section{Normality Analysis}

Table 2 depicts the statistic of skewness and kurtosis. All statistic values were between -1 and +1 . This indicates that all the variables for this study were normally distributed. Thus, the parametric test can be used for the data in this study. 
Table 2. Coefficient of skewness and kurtosis

\begin{tabular}{lcc}
\hline Variables & Skewness & Kurtosis \\
\hline Workload & -.182 & -.5267 \\
Time Pressure & -.065 & -.915 \\
Skill Discretion & -.554 & -.043 \\
Decision Authority & -.287 & .288 \\
Job Performance & -.597 & .261 \\
\hline
\end{tabular}

\section{Descriptive Statistics}

The table below shows that most of the respondents involved in this study were male (50\%). More than $70 \%$ of the STIDC staff were married. $37.5 \%$ or 30 of the respondents have age between 31 to 40 years old and followed by age between 51 to 60 years old (19 or 23.8\%). Most of them have Sijil Pelajaran Malaysia (SPM) for the highest education with a frequency of $38(47.5 \%)$, and only 3 out of 80 respondents or $3.8 \%$ have Master.

Table 3. Demographic profile of respondents

\begin{tabular}{lcc}
\hline & Frequency & $\%$ \\
\hline Gender & 50 & \\
Male & 30 & 62.5 \\
Female & & 37.5 \\
Marital Status & 16 & \\
Single & 61 & 20.0 \\
Married & 3 & 76.3 \\
Divorced & & 3.8 \\
Age & 18 & \\
21-30 years old & 30 & 22.5 \\
31-40 years old & 13 & 37.5 \\
41-50 years old & 19 & 16.3 \\
51-60 years old & & 23.8 \\
Highest Education & 38 & \\
SPM & 6 & 47.5 \\
Matric/STPM & 21 & 7.5 \\
Diploma & 12 & 26.3 \\
Degree & 3 & 15.0 \\
Master & & 3.8 \\
\hline
\end{tabular}

Based on the findings in Table 4, by referring to the 10-point Likert Scale measuring the level of agreement used in this research, in average, the respondents agreed that their skill discretion has an average of 7.62 and standard deviation at 1.52) and then followed by the time pressure (mean=7.00, SD=1.51). However, the respondents also stated that workload has an average of 6.68 and a standard deviation at 1.22, and the average for decision authority is 6.16 and the standard deviation at 1.61. From all the results, it could be said that on the average, respondents agreed that job stress has an impact on job performance. 
Table 4. Mean and standard deviation results

\begin{tabular}{lcc}
\hline Variables & Mean & Standard Deviation \\
\hline Workload & 6.68 & 1.22 \\
Time Pressure & 7.00 & 1.51 \\
Skill Discretion & 7.62 & 1.52 \\
Decision Authority & 6.16 & 1.61 \\
Job Performance & 7.51 & 1.54 \\
\hline
\end{tabular}

\section{Correlation Analysis}

Table 5. Pearson's Correlation among the variables

\begin{tabular}{|c|c|c|c|c|c|}
\hline & 1 & 2 & 3 & 4 & 5 \\
\hline Job performance (1) & 1 & $.495^{* *}$ & $.502 * *$ & $.840 * *$ & $.520 * *$ \\
\hline Workload (2) & & 1 & $.754 * *$ & $.588 * *$ & $.555^{* *}$ \\
\hline Time pressure (3) & & & 1 & $.652 * *$ & $.542 * *$ \\
\hline Skill discretion (4) & & & & 1 & $.503 * *$ \\
\hline Decision authority (5) & & & & & 1 \\
\hline
\end{tabular}

**. Correlation is significant at the 0.01 level (2-tailed).

According to Table 5, result for skill discretion has the strongest correlation with the job performance $(r=.840, p<0.01)$. This showed that employees who have the knowledge or skills could do better in their job (Viotti and Converso, 2016). Time pressure and job performance also significantly correlated to each other $(r=.502, p<0.01)$. It shows a strong positive relationship. The other variable, decision authority, also has a high and significant relationship ( $r=.520, p<0.01)$ towards job performance. When a manager allowed their employees to make a decision, then the employee's performance also will be increase. However, the relationship between workload and job performance showed medium correlation $(r=.495, p<0.01)$. The finding revealed that the quality of the employees' job performance was high when given a moderate amount of workload (Bruggen, 2015). Overall, the results show a strong correlation between job stress and job performance where the value for ' $r$ ' is more than .50. This means that there is a correlation between the independent and dependent variables which is job stress and job performance.

\section{Multiple Linear Regression Analysis}

According to Table 6, there is no multicollinearity problem exists. The problem can be detected when the variance inflation factor (VIF) more than 10 and tolerance values (TOL) less than 0.1. Thus, a regression can be used for the data in this study to estimate the job performance.

About $71.5 \%$ of the variation in the job performance was explained by the variation in the workload $\left(X_{1}\right)$, time pressure $\left(X_{2}\right)$, skill discretion $\left(X_{3}\right)$ and decision authority $\left(X_{4}\right)$, while other variables explained the remaining of $28.5 \%$. The model was significant at $F=50.479$ with a $p$-value of less than 0.01 . The model also was tested by checking the assumptions of error terms. The results found that the error terms have constant variance, independent and normally distributed with mean zero. Therefore, the model is adequate and appropriate for the data. For that reason, the expected model is

$$
\text { Job Performance }=0.928-0.159 X_{1}+0.855 X_{2}+0.161 X_{3}+0.030 X_{4}
$$


Based on the table below, it shows that time pressure and skill discretion were significantly correlated to estimate the job performance. On the other hand, workload ( $\beta=$ $0.159, p>0.05)$ and decision authority $(\beta=0.030, p>0.05)$ were not significant in this model. By making other variable constant, when rating for time pressure increase by 1 unit, the rating for job performance will be increased by 0.855 .

Table 6. Multiple linear regression on job performance

\begin{tabular}{lcccccc}
\hline & Beta & $\begin{array}{c}\text { Standard } \\
\text { Error }\end{array}$ & t-statistic & P-value & $\begin{array}{c}\text { Tolerance } \\
\text { Value (TOL) }\end{array}$ & $\begin{array}{c}\text { Variance } \\
\text { Inflation } \\
\text { Factor (VIF) }\end{array}$ \\
\hline (Constant) & .928 & .55 & 1.672 & .099 & & \\
Workload & -.159 & .102 & -1.557 & .124 & .358 & 2.796 \\
Time pressure & .855 & .083 & 10.249 & .000 & .533 & 1.877 \\
Skill discretion & .161 & .072 & 2.217 & .030 & .632 & 1.583 \\
Decision authority & .030 & .121 & 0.245 & .807 & .393 & 2.546 \\
\hline
\end{tabular}

$\mathrm{N}=80$, Adjusted $\mathrm{R}$ Square $=.715, \mathrm{~F}=50.479$, overall model significance at 0.01

\section{Discussion}

Based on the findings, it can be concluded that there was a positive relationship existed with a medium correlation value for the relationship between workload towards individual work performance $(r=.495, p<0.01)$ and was significant. This is because most of the employees at STIDC capably manage a heavy workload. Besides that, they have been working at the company for years so that they already adapt fast-paced workload also their work is a constant process. Besides, the employees know which task is a priority. So, employees will do the task that very important and urgent and for the task that not urgent they will do later. Employees know when there are many tasks to do given by the manager or their supervisor, usually, they will get a chance to get promotions and to get a higher-level position. The management at STIDC Company was always able to identify the staff that have contributed much in their work, excellent reputation and already understand how to handle a heavy workload and will allow employees to get promoted.

The finding of the study presented the result for time pressure that is shown in table correlation which was a strong, positive and significant relationship $(r=.502, p<0.01)$. From that, it can conclude that the time pressure has a relationship with job performance among staff at selected departments in STIDC. Based on the results that showed a positive relationship between time pressure and job performance, it can be concluded that the employee in the organization experienced time pressure while performing their task because their job was very urgent, and the manager always want the staff to perform work on time and fast when they asked for it.

Next, the results shown skill discretion and employees' job performance among staff from selected departments were correlated. The correlation was a strong, significant and positive relationship $(r=.840, p<0.01)$. Skills discretion can be defined as the extent to which the skills are usable on the job (Karasek, 1979). Also, this positive linear relationship existed due to the management at STIDC should provide the employee with training and sent them to attend courses to enhance their knowledge regarding their job description and job position. Management also always ensure each section will conduct the workshop for their staff and choose a minimum of two participants to attend. The workshop is good for them to increase experience, to boost confidence and so forth. 
Apart from that, in this analysis, there was a significant, positive relationship and strong value between decision authority towards employees' job performance $(r=.520$, $p<0.01$ ). Decision authority is vital in any organization before deciding anything important regarding work. The leader or manager should ask their staff for their opinion or some ideas to get an effective result. Every organization knows that if they want their employees to grow they should empower employees to make their own decisions. Empowerment can reduce time because employees do not need to ask and wait for the approval from the managers and tasks can be completed faster. Eventually, employees can know their ability and advantages of themselves. The top management in STIDC always give the staff opportunities and involve them while making decisions so that it can automatically boost the motivation and feel their presence are being appreciated.

\section{Conclusion}

In a nutshell, this study aimed to explore the factors of employees' job stress that affect job performance among STIDC staff in Sarawak. From the analysis, it showed that the workload, time pressure, skill discretion, and decision authority has correlated with job performance. However, according to the multiple regression analysis, only time pressure and skill discretion significantly affect job performance. The regression model obtained explains $71.5 \%$ of the variance in job performance. The other independent variables were not affecting the dependent variable for this study.

Based on this research about the Relationship between Employees Job Stress and Job Performance, there are a few recommendations that researcher can provide for the future researcher. For a workload that has a medium correlation value towards employees' job performance among staff in STIDC, the manager should have sympathy and understanding when their employees are given excessive workload. Because employees are not a robot and performing too many tasks can be demanding. Other than that, time pressure has a very strong correlation with job performance. To solve this, the manager should not push and not let everything depend on their employees. The manager should know when the staff has already a lot of work to do, do not assign more tasks to them because it can increase the level of stress and make them exhausted. Managers also should give them more time if necessary and not impose on them.

Besides that, STIDC should recognize which employee that show excellent work and award them with a bonus, salary increment, promotion and so forth. Everyone likes to be appreciated so when the management rewards their employees this will keep them motivated. When the top management makes the employees feel appreciated, this will encourage them to be loyal and remain in the company for a long time.

\section{References}

Akgunduz, Y. (2015). The influence of self-esteem and role stress on job performance in hotel businesses. International Journal of Contemporary Hospitality Management, 27(6), 1082-1099. https://doi.org/10.1108/IJCHM-09-2013-0421

Allen, P., Bennett, K., \& King, J. (Ed.) (2010). PASW statistics by SPSS: A practical guide, version 18.0. National Library of Australia.

Bruggen, A. (2015). An empirical investigation of the relationship between workload and performance. Management Decision, 53(10). 2377-2389.

https://doi.org/10.1108/MD-02-2015-0063 
Cho, S. S., Ju, Y. S., Paek, D., Kim, H., \& Jung-Choi, K. (2018). The Combined Effect of Long Working Hours and Low Job Control on Self-Rated Health: An Interaction Analysis. Journal of occupational and environmental medicine, 60(5), 475-480. https://doi.org/10.1097/JOM.0000000000001241

Hafeez, S. (2018). The impact of job stress on performance of employees: A study of social security Hospital of District Okara \& Sahiwal. Journal of Neuropsychology \& Stress Management, 3, 4-12.

Heponiemi, T., Kouvonen, A., Virtanen, M. et al. (2014). The prospective effects of workplace violence on physicians' job satisfaction and turnover intentions: the buffering effect of job control. BMC Health Services Research, 14(1), 19. https://doi.org/10.1186/1472-6963-14-19

Isfahani, H. M., Aryankhesal, A., \& Haghani, H. (2014). The relationship between the managerial skills and results of "performance evaluation "tool among nursing managers in teaching hospitals of Iran University of Medical Science. Global journal of health science, 7(2), 38-43. https://doi.org/10.5539/gjhs.v7n2p38

Johari, R. J., Ridzoan, N. S., \& Zarefar, A. (2019). The Influence of Work Overload, Time Pressure and Social Influence Pressure on Auditors' Job Performance. International Journal of Financial Research, 10(3), 88. https://doi.org/10.5430/ijfr.v10n3p88

Kain, J., \& Jex, S. (2010). Karasek's (1979) job demands-control model: A summary of current issues and recommendations for future research. In P. L. Perrewé \& D. C. Ganster (Eds.), Research in occupational stress and well-being. 8. New developments in theoretical and conceptual approaches to job stress. 237-268. Emerald Group Publishing. https://doi.org/10.1108/S1479-3555(2010)0000008009

Kumar, S. P., \& Saha, S. (2017). Influence of Trust and Participation in Decision Making on Employee Attitudes in Indian Public Sector Undertakings, SAGE Open, 7(3). https://doi.org/10.1177/2158244017733030

Lopes, H., Lagoa, S., \& Calapez, T. (2014). Work autonomy, work pressure, and job satisfaction: An analysis of European Union countries. The Economic and Labour Relations Review, 25(2), 306-326. https://doi.org/10.1177/1035304614533868

Munisamy, S. (2013). Identifying factors that influence job performance amongst employees in oil palm plantation - FASS Final Project (Psychology).

Nunnally, J. C. (1978). Psychometric Theory. New York: Mc-Graw-Hill.

Ramzan, A. A. (2013). Effects of job stress on employees' job performance a study on banking sector of Pakistan. Journal of Business and Management, 11(6), 61-68.

Sekaran, U., \& Bougie, R. (2013). Research methods for business: A skill-building approach. 6th Edn., West Sussex, UK: John Wiley \& Sons Ltd.

Sharma, A., \& Bhatnagar, J. (2017). Emergence of team engagement under time pressure: role of team leader and team climate. Team Performance Management, 23(3), 171-185. https://doi.org/10.1108/TPM-06-2016-0031

Sia, S. K., and Duari, P. (2018). Agentic work behaviour and thriving at work: role of decision making authority. Benchmarking: An International Journal, 25(8), 3225-3237. https://doi.org/10.1108/BIJ-07-2017-0204

Viotti, S., \& Converso, D. (2016). Relationship between job demands and psychological outcomes among nurses: Does skill discretion matter?. International journal of occupational medicine and environmental health, 29(3), 439-460. https://doi.org/10.13075/ijomeh.1896.00520 
Willemse, B. M., de Jonge, J., Smit, D., Depla, M. F., \& Pot, A. M. (2012). The moderating role of decision authority and coworker- and supervisor support on the impact of job demands in nursing homes: a cross-sectional study. International journal of nursing studies, 49(7), 822-833. https://doi.org/10.1016/j.ijnurstu.2012.02.003 